\title{
THE SO CALLED “TRIASSIC BRECCIAS” OF THE IONIAN ZONE IN GREECE AND ALBANIA: THEIR STRATIGRAPHIC POSITION AND THE ENSUING TECTONIC IMPLICATIONS
}

\author{
G. GUZZETTA ${ }^{1}$ AND I. REPOLA ${ }^{2}$
}

\begin{abstract}
Field observations are reported which show that: 1) at least part of the so called "Triassic breccias" of the Ionian isopic zone actually represent a local variant of the basal breccias of a Middle-Upper Miocene marine terrigenous sequence; 2) other portions of the same Miocenic basal breccias have been often mistaken in the past for some other looking-like terrane of different age (from Jurassic to Quaternary!). Since some currently accepted inferences on the time-sequence of both sedimentary and tectonic events ensuing from the above misunderstandings become questionable, new field investigation should be extended to the entire Ionian zone with due regard to the above terranes.
\end{abstract}

KEY WORDS: Ionian zone, Triassic breccias, stratigraphy, tectonics, evaporites, hydrocarbons, Greece, Albania.

\section{INTRODUCTION}

Distinct Mesozoic belts of strata exhibiting similar facies along their length have been recognized in the southern branch of the Dinarides known as the Hellenides (Kober, 1929). The fact that each of these isopic (the opposite of heteropic) zones underwent different styles of deformation, led Aubouin to use the area as the typeexample for his version of geosynclinal model late in the fifties $(1959,1963,1965)$. Afterward the Hellenic orogenic belt has been considered as resulting from development, foundering, and eventually shortening of a passive continental margin associated with early Mesozoic opening and late Mesozoic-early Cenozoic closure of the Neotethyan Ocean (Underhill, 1985). Several well-definite thrust sheets developed as a consequence of ocean closure. Thrusting and emplacement initially developed on the site of Neotethys and migrated progressively toward the foreland (Smith and Moores, 1974; Dewey and others, 1973).

The external Hellenides lying to the west of the Pindos thrust are subdivided into three isopic zones. From East to West they are: (1) the Gavrovo-Tripolitza, (2) the Ionian and (3) the Pre-Apulian zones (Aubouin, 1959, 1965; Aubouin and Dercourt, 1962; Aubouin and others, 1976; Temple, 1968; Jenkins, 1972; Smith and Moores, 1974). The Gavrovo-Tripolitza and Ionian zones have been considered to represent the external large thrust sheets emplaced onto the stable Pre-Apulian autochthon as part of the latest Hellenide events. Terranes of the Ionian zone - generally considered to represent the most external deformed belt - outcrop from southwestern Albania to western Peloponnesus.

The Ionian zone is a fold and thrust belt consisting of Mesozoic mostly carbonate rocks and a Cenozoic flysch. Its deformation probably initiated during Eocene-Early Oligocene and reached a maximum rate in late Oligocene-Miocene (Sejdini et al., 1994; Roure et al., 1995). Middle-Upper Miocenic clastic rocks unconformably overlay the older deformed and eroded terms. Some authors hold that tectonic displacements fade out going westward from the Gavrovo-Tripolitza zone to the Pre-Apulian; others believe that the Triassic evaporites encountered in some wells under the older terranes of the stratigraphic column of figure 1 (B.P., 1971) represent an important imbricated dicollement surface even in the Ionian zone (Gill, 1964; Guzzetta, 1982 ; B.P., 1971; Underhill, 1985).

The existence of real exposures of the same Triassic terranes encountered underground is somewhat controversial. Actually, the breccias exposed in some broad strips along the Ionian zone, include masses of gypsum and black or dark-gray limestones, the latter ones containing Cardita Gómbeli PICHLER (Renz, 1955), and clasts with Triassic microfossils (Dragastan et al., 1985; Pomoni-Papaioannou and Tsaila-Monopolis, 1983). They are currently described as un-bedded bodies made up of angular fragments of vuggy limestones and dolomites and/

1. Università di Napoli "Federico II", Dipartimento di Geofisica e Vulcanologia - Largo San Marcellino, 10 - 80132 NAPOLI - ITALIA

2. Viale Mellusi, 91 - 82100 BENEVENTO - ITALIA 
or of a greysh or brown silt associated with blocks or fragments of black, foetid, fine-grained dolomite, resting on various beds from Cretaceous to Miocene. In the opinion of the British Petroleum geologists, the drilling of a borehole near Aitolikon (western Greece) offered some evidence that these breccias were derived from the fragmentation of part of the Triassic evaporite series (B.P., 1971).

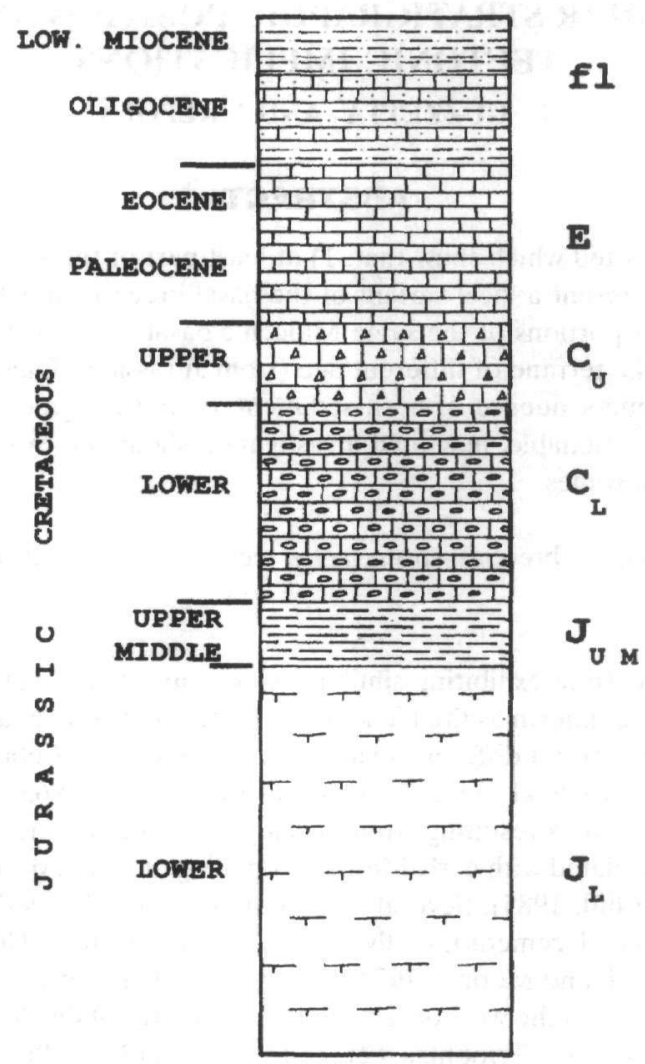

FIGURE 1 - Simplified stratigraphic column of the Ionian zone (excluding Triassic terranes). $J_{L}$ : Pantokrator neritic massive limestones and dolostones; $J_{U M}$ : Posidonia cherts and Ammonitico Rosso (Heteropies and minor unconformities); $C_{L}$ : Vigla pelagic limestones with cherts; $C_{U}:$ Senonian lutites with coarse carbonate clasts; $E$ : Eocene pelagic lutites; fl: flysch.

These breccias have been interpreted as remnants of the cap-rock of leached salt diapirs (Bornovas, 1960), or resulting from fragmentation of intercalated rocks both during (I.G.R.S.-I.F.P., 1966) or after (PomoniPapaioannou, 1980; Karakitsios, 1992; Karakitsios and Pomoni-Papaioanou, 1998) the injection of the salt masses, or as tectonic breccias (Guzzetta, 1982), or originating from diapirism assisted by thrusting. Formerly considered as Tertiary sediments, they hare now currently known as "Triassic breccias", mapped as a single formation of Triassic age (I.G.R.S., 1969; I.G.R.S.-I.F.P, 1966) and represented in the stratigraphic sections as lying underneath the oldest outcropping terranes. Some authors (Underhill, 1988) maintain that, although the evaporites are not commonly exposed, perhaps because they are covered by the brecciated carbonated cap rock (see also Velaj et al., 1999), somewhere occasional isolated outcrops occur whose fabric has been supposed to show that diapirism here had a complex history.

The present paper deals with new field data concerning the origin and stratigraphic position of the abovementioned "Triassic breccias" and the sequence of tectonic events in the folded belt of Western Greece and South-western Albania. The new findings result from a very detailed geological mapping of most of the 1:50.000 sheets Igoumenitsa, Paramithià and Parga (Greece) and field observations in a number of sites in South-western Albania and Western Greece. They make questionable some current interpretations of the available indirect information on subsurface structures of a region that seems still to be an attractive proposition for oil explora- 
tion.

\section{STRATIGRAPHIC POSITION OF THE "TRIASSIC BRECCIAS"}

Our exhaustive field work, done mostly within the Parga region in Epirus, roughly substantiates what has been already recognized about the outcropping conformable sequence of marine terranes deposited from the Upper Trias to the Lower Miocene. In the studied areas, neritic carbonates of the lower Jurassic are followed by pelagic sediments (mostly carbonates) initially characterized by some heteropy and minor disconformities (Middle and Upper Jurassic), with an Oligocenic-Miocenic flysch overlaying the youngest pelagic (Eocenic) limestones (fig. 1).

On the contrary, we found plenty of field evidence that throws new light on the relationships among the above terranes, the Middle-Upper Miocenic clastic sediments which have been deposited uncorformably over them, and the so called "Triassic breccias".

The uncorfomable Middle-Upper Miocenic sequence consists of unlayered breccias and/or coarse layered clast- and matrix-supported conglomerates, followed by sands and sandy marls. Yhe poorly sorted basal breccias, inclusive of large olistholites, are characterized by widely variable thikness, composition and external semblance, but their common age may be recognized in a number of places where the upper fossiliferous terms of the sequence escaped erosion. Field evidence shows that rudites already misinterpreted as sediments of different age (from Mesozoic to Quaternary), make up, all together, the basal terms of the Upper-Middle Miocenic marine sequence.

The sketch of figure 2, drawn taking into account all the sequences (1 to 9 ) exposed in a wide area around Parga (covering about four 1:50.000 sheets), is a synoptic representation of all the documented relationaships among the outcropping terranes. It shows that the Middle-Upper Miocenic clastic sediments overlay the folded, faulted and deeply eroded series of marine terranes represented in figure 1 . Somewhere, the unbedded transgressive Miocenic breccias are nothing but the so called "Triassic breccias" whose clasts have been supposed to originate from erosion of rocks belonging to the Triassic evaporite series (type $\mathbf{M b}^{\prime}$, on the left of figure 2, while elsewhere they consist only (or mostly) of clasts derived from all the younger formations of the exposed series (type Mb", on the right of figure 2). Both these main variants appear intercalated in Arilla, southwest of the village of Perdika (sequence 5, center of figure 2; $20^{\circ} 17^{\prime} 28^{\prime \prime} \mathrm{E} 39^{\circ} 21^{\prime} 43^{\prime \prime} \mathrm{N}$ ); a gradual vertical transition, characterized by mixture of clasts of both the above sources, may be observed in the sequences 2,4 and 6 of figure 2 , respectively along the new road Parga-Perdika southwest of Perdika (approximately $20^{\circ} 18^{\prime} 3^{\prime \prime} \mathrm{E} 39^{\circ} 18^{\prime} 46^{\prime \prime} \mathrm{N}$ ), near the Kastro west of Anthousa $\left(20^{\circ} 22^{\prime} \mathrm{E} 39^{\circ} 18^{\prime} 25^{\prime \prime} \mathrm{N}\right)$, along the asphalt road south of Aghia Kyriak $\mu$ $\left(20^{\circ} 26^{\prime} 50^{\prime \prime} \mathrm{E} 39^{\circ} 16^{\prime} 59^{\prime \prime} \mathrm{N}\right)$. Both the variants $\mathbf{M b}^{\prime}$ and $\mathbf{M b}^{\prime \prime}$ may lie directly on terranes belonging to the deformed and eroded series. The variant $\mathbf{M b}^{\prime}$ is resting on them in the already mentioned 6 and in the sequences 1 and 3, respectively along the road Parga-Perdika $\left(20^{\circ} 20^{\prime} 12^{\prime \prime} \mathrm{E} 39^{\circ} 20^{\prime} 45^{\prime \prime} \mathrm{N}\right)$, and along the coast of the Ormos Aghiou Ioannou $\left(20^{\circ} 27^{\prime} 58^{\prime \prime} \mathrm{E} 39^{\circ} 16^{\prime} 50^{\prime \prime}\right)$; the variant $\mathbf{M b}^{\prime}$ in the sequences 7,8 and 9, near Grava $\left(20^{\circ} 18^{\prime} 5^{\prime \prime} \mathrm{E}\right.$ $\left.39^{\circ} 19^{\prime} 25^{\circ} \mathrm{N}\right)$, near Akros Trofali $\left(20^{\circ} 23^{\prime} 46^{\prime \prime} \mathrm{E} 39^{\circ} 17^{\prime} 10^{\prime \prime} \mathrm{N}\right)$ and at the Venetian castle of Parga $\left(20^{\circ} 20^{\prime} 20^{\prime \prime} \mathrm{E}\right.$ $39^{\circ} 17^{\prime} 20^{\prime \prime}$ ) respectively.

\section{TECTONIC OUTCOMES}

Because of their manifold appearance, here and there the above described basal breccias have been mapped, not only as part of the Middle-Upper Miocene and as "Triassic breccias", but also as Liassic massive neritic dolostones and limestones (Pantokrator formation; see, for instance, at the Kastro, west of Anthousa), Lower Cretaceous lutites with cherts (Vigla formation; in Arilla, southwest of the village of Perdika), and even as cemented Quaternary screes, between Anthousa and Parga (Parga sheet of the IGME geological map 1:50.000; Epirus geologial map 1:100.000 in I.G.R.S.-I.F.P., 1966; Guzzetta, 1982; Sorel, 1989).

The above mentioned misunderstandings led to interpretations of the local tectonic structure which are not consistent with the above new findings. Among other things, the very existence of the overthrusting of the "Parga Unit” (I.G.R.S.-I.F.P., 1966; Sorel, 1989) over Upper Miocenic and even younger (Pliocenic) terranes becomes doubtful (showing, among other things, that some assumptions made in the past by one of the authors were erroneous; Guzzetta, 1982). Just to mention one of the many pieces of evidence, north of the Parga village the rocks making up the steep cliff dramatically crowning the lower angle slope have been mapped as massive limestones and dolostones of Liassic age (Pantokrator formation) tectonically superposed over the Upper-Middle Miocenic sands and sandy marls exposed at lower altitude. Actually the cliff is mostly made of the basal breccias of the Upper-Middle Miocenic sequence which are exposed again at a far lower altitude in the Parga 


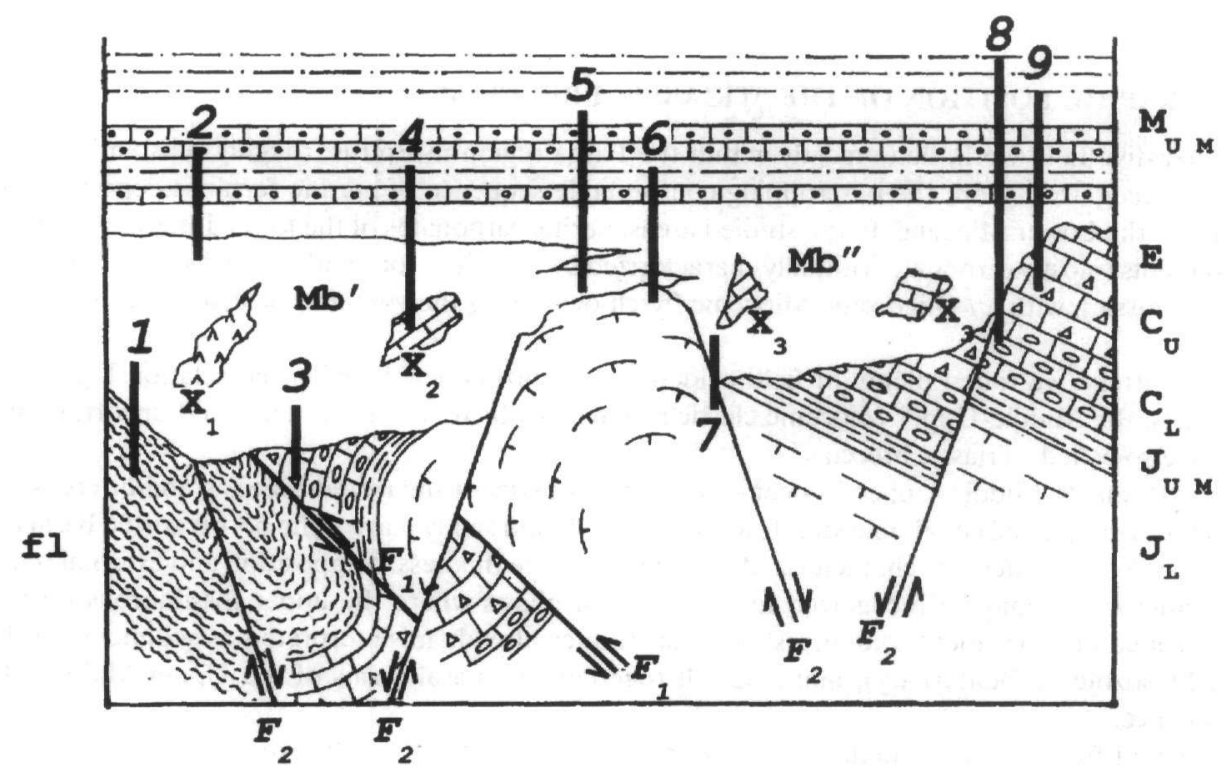

FIGURE 2 - Synoptic sketch, based on sedimentary sequences (1 to 9) and tectonic structures observed in the Ionian zone, showing the succession of depositional, erosional, and tectonic events from the Oligocene-Lower Miocene folding to the sedimentation of the Middle-Upper Miocenic terranes.

$J_{L}, J_{U M} C_{L}, C_{U} E$ and $f l$ : terranes belonging to the stratigraphic column of figure 1; Mb": breccias, mostly made of clasts originating from erosion of terrains making up the series of figure 1, already known as the basal term of the Middle-Upper Miocenic sequence; Mb': breccias, mostly originating from erosion of exposed older evaporitic terranes and currently mapped as "Triassic breccias", representing a local variant of the basal breccias of the same Middle-Upper Miocenic sequence; $M_{U M}$ sands and sandy marls of the same sequence; $X_{I}$ : gypsum olistholite; $X_{2}$ : fossilipherous limestone olistholite; $X_{3}$ : limestone olistholites; $\mathrm{F}_{1}$ : thrust associated with the folding accompaining and following the flysch deposition; $\mathrm{F}_{2}$ : normal faulting followed by and/or associated with the deposition of the Middle-Upper Miocenic sediments.

bay. Plenty of field evidence concurs in showing that the present day setting results from dip-slip displacements on sets of almost vertical faults, instead of being the consequence of a replay of the Oligocene-Lower Miocene low angle thrusts. An easy and pleasant walk from the Venetian castle of Parga to the equally accessible Turkish kastro of Anthousa could be enough to be persuaded.

\section{CONCLUSIONS}

Production of frequent and widespread debris flows seems to have preluded to the deposition of a MiddleUpper Miocene terrigenous marine sequence in the Ionian zone of Albania and Greece. This phenomenon could be put in relationship with an extensive tectonic phase responsible for topography rejuvenation and ensuing fast erosion. The short distances the clasts covered gave rise to deposits of different composition from place to place, depending on the locally outcropping rocks. Field evidence shows that at least part of the breccias already mapped as "Triassic breccias" in Greece is a particular variant of these deposits. They are prevailingly made up of clasts originating from erosion of then exposed rocks belonging to the evaporitic Triassic sequence. These breccias rest on sediments whose age is older than Upper Miocene, including the Triassic ones from which they derive, like in the Dumre region in Albania (Aliaj, 1999; Velaj et al., 1999). Even today, evaporitic terranes could be directly exposed in a number of places, like, for instance, near the Bistrina river in southern Albania (Cirilli e Montanari, 1994). Unfortunately, it is likely that other exposures of Triassic terranes haven't been distinguished from those of the far younger Middle-Upper Miocenic "Triassic breccias" resulting from their erosion.

Other polygenic and monogenic types of breccias of the same Middle Miocenic age locally resulted from the dismantling of rocks younger than Triassic. Here and there they have been recognized as the basal term of the Miocenic sequence, but in a number of places the same unbedded rudites, roughly resembling some other terrane outcropping in the area, have been mistaken for the latter. 
The recognition of both the above misunderstandings seems to invalidate some current opinions on the succession of sedimentary and tectonic events and on local and regional structures, suggesting the need for further field investigations. Of course, such a need may become more urgent if important interests are at stake.

\section{REFERENCES}

ALIAJ SH., 1999. Transverse faults in Albanian orogen front, Albanian Journal of Natural \& Technical Sciences, 6, 121-132.

AUBOUIN J., 1959. Contribution a l'itude gıologique de la GrOce septentrionale: les confins de l'Epire et de la Thessalie, Ann. Geol. Pays Hell., 10, 1-125.

AUBOUIN J. et al., 1963. Esquisse de la gıologie de la GrOce, In: Livre v̂ la mımoire de Paul Fallot, 2, Soc. gıol. de France, 583-610.

AUBOUIN J., 1965. Geosynclines, Development in Geotectonics, Elsevier.

AUBOUIN J., J. DERCOURT, 1962. Zone Preapulienne, zone Ionienne et zone du Gavrovo en Peloponnese occidental, Bull. Soc. gıol. de France, 4, 6, 785-793.

AUBOUIN J. et al., 1977. Rıunion extraordinaire de la Socitt gıologique de France en GrAce co-organiste avec la Socitt gıologique de GrӨce (9-20 septembre 1976), Compte rendu coordonnt par Jean Dercourt, Bull. Soc. giol. France, (7), XIX, 5-70.

BORNOVAS J., 1960. Observations nouvelles sur la gıologie des zones prtapulienne et ionienne (GrOce occidentale), Bull. Soc. giol. France, (7), II, 410-414.

CIRILLI S. and L. MONTANARI, 1994. Palaeopelagos, 4, 107-118.

DEWEY, J.F., W.C. PITMAN, and W.B.F. RYAN, 1973. Plate tectonics and the evolution of the Alpine system, Geol. Soc. Of America Bull., 84, 3137-3180.

DRAGASTAN O., P. PAPANIKOS, 1985. Foraminif0res, Algues et microproblematica du Trias de Messopotamos, Epire GrOce continentale), Revue de Micropaleontologie, 27, 244-248.

GILL W.D., 1964. The Mediterranean Basin, in 'Salt basins around Africa, Institute of Petroleum', London, 122 pp.

GUZZETTA G., 1982. Thin-skinned style of deformation in Epirus, Proceedings International Symposium on the Hellenic Arc and Trench (H.E.A.T.), 1, 151-175.

I.G.R.S.-I.F.P. (Institut de Geologie et Recherches du Sous-sol - Institut Franyais du Petrole), 1966. Etude gıologique de l'Epire (GrӨce nord-occidentale), Editions Technip, Paris, 306pp.

I.G.R.S, 1969. Geologic map 1:50.000, sheet Parga.

JENKINS D.A.L., 1972. Structural development of western Greece, A.A.P.G Bull., 56, 128-149.

KARAKITSIOS V., 1992. Ouverture et inversion tectonique du basin ionien (Epire, GrAce), Ann. Geol. Pays Hell., 35, 185-318.

KARAKITSIOS V. and F. POMONI-PAPAIOANNOU, 1998. Sedimentological study of the Triassic solution collapse breccias of the Ionian zone (NW Greece), Carbonates \& Evaporites, 13, 2, 207-218.

KOBER L., 1929. Die Grossgliederung der Dinariden, Cent.f. Min., etc., Abt. B, 426-427.

POMONI-PAPAIOANNOU F. and S. TSAILA-MONOPOLIS, 1983. Rivista Italiana di Paleontologia e Stratigrafia, 88, 387-400.

RENZ C., 1955. Stratigraphie Griechenlands, I.G.R.S., Athens, 637 pp.

ROURE F., E. PRENIASI, and Z. XHAFA, 1995. Albania: petroleum geology of the Albanian thrust belt, A.A.P.G. International Conference and Exhibition, Excursion 7 Field Trip Notes, 46.

SEJDINI B., P. COSTANTINESCU, and T. PIPERI, 1994. Petroleum exploration in Albania, in B. Popescu, ed., Hydrocarbons of eastern central Europe, Heidelberg, Springer-Verlag, 1-28.

SMITH A.G. and E.M. MOORES, 1974. Hellenides, in Spencer A.M., ed., Mesozoic and Cenozoic orogenic belts, Geological Society of London Spec. Publ. 4, 159-185.

SOREL D., 1989. L'evolution structurale de la GrӨce nord-occidentale depuis le Miocene dans le cadre gıodynamique de l'Arc Egıen, ThӨse Doctorat, Universitı de Paris-Sud Centre Orsay, 297 pp.

TEMPLE P.G., 1968. Mechanics of large-scale gravity sliding in the Greek Peloponnesos, Geol. Soc. of America Bull., 79, 687-700.

UNDERHILL J. R., 1985. Neogene and Quaternary tectonics and sedimentation in western Greece, $\mathrm{PhD}$ Thesis, University of Wales, Cardiff.

UNDERHILL J. R., 1988. Triassic evaporites and Plio-Quaternary diapirism in western Greece, Jour. Geol. Soc. of London, 145, 269-282.

UNDERHILL J. R., 1989. Late Cenozoic deformation of the Hellenic foreland, W. Greece, Geol. Soc. of America Bull., 101, 613-634.

VELAJ T., I. DAVISON, A. SERJANI, I. ALSOP, 1999. Thrust tectonics and the role of evaporites in the Ionian zone of the Albanides, A.A.P.G. Bull., 83, 9, 1408-1425. 